\title{
PERAN IKLAN MEDIA SOSIAL DALAM MENINGKATKAN VOLUME PENJUALAN
}

\author{
Almayanti ${ }^{1}$, Ramliana ${ }^{2}$, Haerunnisa ${ }^{3}$, Dina Fajriani Azis ${ }^{4}$, Faiqah Mas'ud ${ }^{5}$, Khuznul \\ Khatimah $^{6}$, Nur Rahmia Syam ${ }^{7}$, Mufti Perdana ${ }^{8}$, Muh. Ikhsan ${ }^{9}$, Muh. Sabrina ${ }^{10}$, \\ Gilang Ramadhan ${ }^{11}$, Abdurrahim ${ }^{12}$ \\ Fakultas Ekonomi dan Bisnis Islam
}

\begin{abstract}
Abstrak
Suatu pemasaran merupakan proses mengidentifikasi dan memenuhi kebutuhan manusia sosial seperti halanya perusahaan menciptakan suatu nilai kepada pelanggan serta membangun hubungan kuat dengan para pelanggan. Sehingga terdapat empat bauran atau hal yang harus dilakukan yaitu: produk (product), harga (price), tempat (place), dan promosi (promotion). Seiring perkembangan teknologi, media promosi semakin bertambah salah satunya melalui media internet. Dari studi kasus ini Peran iklan terhadap volume penjualan Frestea memiliki pengaruh yang sangat signifikan dan terhadap keputusan pembelian produk Frestea. Sehingga semakin tinggi terpaan iklan Frestea terhadap media periklanan akan berpengaruh terhadap peningkatan persentase pembelian produk Frestea sehingga akan meningkatkan persentase pembelian produk Frestea dan komunikasi word of mouth berpengaruh sangat signifikan dan positif terhadap peningkatan pembelian produk Frestea. Sehingga semakin tinggi faktor komunikasi word of mouth juga akan berpengaruh terhadap semakin meningkatnya penjualan produk Frestea
\end{abstract}

\section{LATAR BELAKANG}

Kondisi bisnis seperti pada masa saat ini semakin maju sebab di dukung oleh berkembangnya teknologi maka membutuhkan konsep untuk mencapai tujuan kesuksesan bagi perusahaan. Konsep merketing berawal dari satu pemikiran yang berujuan tercapainya laba jangka, sehingga perusahaan harus dapat memahami kebutuhan palanggan dan juga keinginannya, harus membagi pasarnya ke dalam segmen-segmen atau kelompok konsumen serta menentukan keinginan dari masing-masing segmen tersebut. Pemasaran harus dipahami tidak hanya dalam pemahaman kuno, tetapi dalam 
mendistribusikan, maupun mempromosikan produk dan jasa itu secara efektif, produk dan jasa sehingga mudah terjual.

Pemasaran dapat diartikan sebagai proses ketika perusahaan menciptakan nilai untuk pelanggan dan membangun hubungan yang kuat pada pelanggan, sehingga tujuan menangkap nilai dari pelanggan sebagai timbal baliknya. Di dalam perusahaan terdapat empat bauran atau hal yang harus dilakukan oleh setiap perusahaan, adalah: produk, harga, tempat, dan juga promosi. Promosi merupakan kegiatan yang penting dimana perusahaan melaksanakan dan juga dalam memasarkan produk maupun jasa yang ditawarkan perusahaan. Sedangkan promsi itu sendiri dapat diartikan arus informasi satu arah yang dibuat untuk mengendalikan seseorang atau organisasi kepada tindakan yang menciptakan pertukaran dalam pemasaran.

Promosi adalah unsur yang penting dalam suatu perusahaan yang dapat memberikan informasi dan menarik minat konsumen untuk mengenal produk yang ditawarkan secara langsung. Sebagai salah satu komponen bauran pemasaran, promosi memegang peranan penting dalam strategi pemasaran yang dilakukan perusahaan. Promosi adalah suatu bentuk kesatuan khusus kegiatan promosi penjualan, yang dapat menghubungan masyarakat dan periklanan yang digunakan oleh perusahaan dalam kegiatan pemasarannya untuk mencapai tujuan pemasaran dan iklan dari suatu produk. Pandangan ekonomi Islam kepemilikan harta tidak dapat dibangun dengan mendestruksi nilai-nilai agama sebagaimana halnya dalam ekonomi kapitalisme, juga tidak memberikan peluang kepada kebebasan mutlak kepemilikan individu, karena mengakibatkan harta terkonsentrasi pada segelintir golongan elit tertentu, yang dapat meciptakan distrosi dalam perekonomian. (Sirajuddin \& Tamsir, 2019)

Dengan semakin banyaknya perusahaan-perusahaan yang ada dipasar maka akan berakibat timbulnya persaingan antara perusahaan-perusahaan tersebut, baik persaingan antara perusahaan sejenis maupun persaingan antar perusahaan yang tidak sejenis. Agar perusahaan dapat bertahan hidup dan dapat bersaing maka perusahaan dituntut untuk mengadakan perbaikan dan peningkatan kegiatan dibidang pemasaran. Penentuan strategi pemasaran yang tepat akan mendorong pembelian konsumen dalam jumlah yang banyak.

Menurut Rangkuti (2009: 51) dalam bukunya strategi promosi yang kreatif dan analisis kasus integrated perusahaan melakukan kegiatan promosi dengan tujuan utama 
yaitu mencari laba. Promosi mengambil peranan penting dalam meningkatkan volume penjualan karena penjualan berhubungan dengan kelangsungan perusahaan yang bersangkutan. Perusahaan dalam mencapai tujuan tersebut harus lebih mementingkan kebutuhan dan keinginan konsumen yang berarti perusahaan membuat apa yang dapat dijual, bukan menjual apa yang dibuat. (Musdalifah, 2013) Apa lagi dalam kegiatan promosi dan penjualan mengalami berbagai hambatan, berarti perusahaan mengalami kesulitan pemasaran yang dihasilkan sehingga akan menurunkan volume penjualan.

Peranan promosi dan penjualan disektor pemasaran produk yang dihasilkan akan menunjang tugas bagian penjualan serta mengenal dan mencari para konsumen atau pemakai, bahkan diusahakan untuk mendapatkan pelanggan. Begitu pentingnya sektor pemasaran, maka sudah sewajarnya perusahaan mengetahui apa, dimana dan bagaimana strategi pemasaran digunakan. Peranan pemasaran dari kemampuannya perusahaan untuk lebih berperan dipasar dengan memanfaatkan dan mencari peluang pasar. Besaran pemasaran merupakan pernyataan yang dinyatakan secara kuantitatif dari segi fisik atau volume atau unit suatu produk. Naik turunya volume penjualan dapat dinyatakan dalam bentuk unit, ton, kilo / liter. Volume penjualan merupakan jumlah total yang dihasilkan dari kegiatan penjualan barang. Semakin besar jumlah penjualan yang dihasilkan perusahaan, semakin besar kemungkinan laba yang diperoleh perusahaan.

Perkembangan informasi dan teknologi (IT) saat ini memang sangat massif di semua kalangan. Pertumbuhannya bahkan sangat cepat membuat orang-orang berlarian agar tidak ketinggalan informasi. Percepatan teknologi dan informasi yang juga menyentuh dunia bisnis pada akhirnya membuat para pelaku pebisnis juga harus ikut mengupdate dan menyesuaikan dirinya pada perkembangan IT tersebut. Seiring perkembangan teknologi, media promosi bertambah semakin banyak, adapun contohnya melalui media internet. Dengan ini setiap perusahaan akan mengurangi biaya untuk mempromosikan produknya. Di Indonesia sendiri penggunaan media sosial sangat berkembang pesat. Menurut riset Nielsen menunjukkan tingkat pertumbuhan penggunaan internet di Indonesia mencapai 26\%. Masyarakat Indonesia menghabiskan waktu 1,5 jam sehari untuk berinternet. Menurut ICT Watch, saat ini pengguna ponsel di Indonesia mencapai 180 juta orang dari 220 juta penduduk Indonesia. 
Pebisnis pada era ini kebanyakan bergelut di bidang teknologi internet. Sudah bukan zamannya lagi kini pebisis harus melakukan promosi dengan metode konvensional dengan melalui media cetak seperti, koran dan majalah atau media elektronik seperti radio, televisi. Hal yang demikian ini terjadi karena telah hadirnya pilihan dan alternatif baru dalam kegiatan promosi bisnis para pengusaha yang sangat berpotensi besar mencapai konversi. Pilihan dan alternatif yang dimaksud adalah media online. Media online yang memanfaatkan jaringan internet sekarang memang sudah bukan sesuatu yang asing lagi bagi para pebisnis. Dengan kemudahan, efisiensi dan efektivitas yang ditawarkannya, media online menjadi pusat perhatian banyak orang. Media ini juga menjadi salah satu bidang pemasaran yang menunjang tingkat penjualan meningkat melalui pengiklanan. Mengiklankan produk pada era digital seperti ini jauh lebih mudah dan lebih murah, seiring dengan perkembangan zaman dimana masyarakat menggunakan media sosial sebagai sumber informasi karena sifatnya yang mudah dan cepat. Hal ini yang mendasari banyak pemilik usaha memasarkan produknya lewat media sosial.

Berdasarkan uraian diatas, maka penulis tertarik untuk memilih judul artikel tentang "Peran Iklan Media Sosial Dalam Meningkatkan Volume Penjualan pada produk Frestea dari PT. Coca-cola Amatil Indonesia"

\section{PEMBAHASAN}

Iklan menggambarkan tempat komunikasi terhadap produk yang disampaikan melalui beberapa media dengan biaya pemrakarsa agar konsumen tertarik akan apa yang ditawarkan. Iklan secara sederhana juga merupakan instrumen atau sarana untuk mempromosikan dan memasarkan barang dalam masyarakat industrial. (Pujiyanto.2001:3-4). Ketika industri berkembang makin masif, dan berbagai produk industri budaya mulai ditawarkan ke masyarakat, konsumen makin beragam dan kompetetif, maka yang terjadi kemudian adalah masing-masing kekuatan komersial mau tidak mau harus memanfaatkan iklan dan mengembangkan strategi yang benar-benar efektif untuk menebus pasar, dan memperluas pangsa pasar yang menjadi pelanggan setia produk-produk yang mereka hasilkan. Sebuah produk yang dilempar ke pasar tanpa didukung promosi melalui iklan-iklan di media massa atau ruang publik lainnya, bukan tidak mungkin pelan-pelan akan terlempar dari pasar dan tidak di minati konsumen. 
Iklan menurut Berkhouver adalah setiap pernyataan yang secara sadar ditujukan kepada publik dalam bentuk apa pun, yang dilakukan peserta lalu lintas perniagaan untuk memperbesar penjualan barang-barang dan jasa. Di Indonesia sendiri, istilah iklan dipopulerkan untuk menggantikan istilah advertentie (bahasa Belanda) dan advertising (bahasa Inggris) (Kasiyan, 2008: 148). Menurut (Thomas M. Garret SJ, dalam Kasiyan, 2008: 149) menyatakan bahwa, iklan adalah ajakan penyampaian pesan-pesan visual atau oral kepada para calon konsumen, dengan bertujuan memberitahukan atau memengaruhi mereka untuk membeli barang-barang dan jasa-jasa yang dihasilkan, atau untuk melakukan tindakan-tindakan ekonomi terhadap ide-ide, institusi-institusi atau pribadipribadi yang terlibat dalam iklan tersebut.

Burke menyatakan periklanan merupakan sebuah kegiatan menyampaikan pesan penjualan kepada masyarakat melalui berbagai cara yang bertujuan menjual produknya, jasa ataupun ide-ide yang bisa disalurkan, salah satunya adalah promosi (Alma, 2005: 182). Dalam kegiatan promosi pemasaran dibutuhkan untuk meningkatkan penjualan. Penggunaan promosi merupakan Langkah yang dapat dilakukan untuk memperkenalkan produk kepada konsumen.

Masyarakat pada era post-modern meyakini bahwa iklan memang bukan sekedar media untuk mempromosikan sebuah produk, tetapi iklan boleh dikata telah menjadi sebuah sistem ide yang mampu mempengaruhi dan mengkonstruksi cita rasa atau selera masyarakat. Pada zaman Yunani Kuno, iklan tak ubahnya seperti pengumuman yang ditulis pada lembaran papirus dan dipancang di dinding-dinding kota dengan tujuan mempromosikan ide tertentu atau menginformasikan sesuatu hak yang dianggap penting. Pada masa Romawi kuno, iklan sering kali tampil bentuk ajakan atau seruan untuk hadir di suatu acara ditempelkan di tembok-tembok pengumuman kota Roma, seperti undangan melihat pertempuran berdarah para gladiator di Coloseum dan info-info penting lainnya.

Masa kapitalisme merupakan awal mulai berkembangnya iklan, yang umumnya lebih banyak berupa poster-poster yang di tempel di berbaik sudut kota, dengan warna yang menarik perhatian masyarakat. Perkembangan iklan menjadi makin masif ketika Guntengberg dan Mainz Jerman pada tahun 1450 menemukan mesin percetakan.

Kasiyan, (2008: 197) juga menegaskan, bahwa masyarakat pada era post-modern, melihat perkembangan iklan tidak hanya dari sekedar pengumuman ringan, 
penyebarluasan informasi, dan promosi barang menjadi organisasi bisnis raksasa para kapitalis, akan tetapi iklan juga mampu mengeksploitasi nilai guna dengan nilai tukar yang semu, dengan serangkaian image untuk meyebarkan benda-benda ke konsumen. Lewat iklan, para produsen tidak hanya memberikan informasi tetang produk yang bisa dikonsumsi masyarakat, melainkan secara terus menerus mempengaruhi, membujuk, merangsang, dan menciptakan kebutuhan baru dalam masyarakat kontemporer secara seragam dan universal.

Penggunaan internet pada masa dewasa ini, telah berubah menjadi alat informasi dan komunikasi internasioanl dalam dunia bisnis. Salah satu kegunaannya adalah sebagai media promosi untuk yang bertujuan untuk mempublikasikan produk atau mengiklankan melalui internet. Sebagai salah satu media untuk menawarkan iklan, yaitu teknologi seperti internet yang menjadi alat yang di gunakan dalam melakukan kegiatan jual beli serta informasi suatu brand yang disebut sebagai E-Commerce (Rahmawati, 2016).

Pada dasarnya Periklanan adalah bagian dari kehidupan industry modern, dan hanya bisa ditemukan di negara-negara maju atau negara-negara yang tengah mengalami perkembangan ekonomi yang pesat. Kebutuhan akan adanya periklanan berkembang seiring dengan ekspansi penduduk dan pertumbuhan kota-kota yang dipenuhi oleh banyak toko, restoran, dan pusat perdagangan besar. Perkembangan periklanan juga ikut dipengaruhi oleh tumbuhnya pola-pola produksi secara massal di berbagai pabrik. Terbukanya jaringan komunikasi darat (dalam bentuk jalan raya dan rel-rel kereta api) yang mengalirkan berbagai barang dari satu tempat ke tempat lain, serta terbitnya suratsurat kabar popular yang menjadi lapak menarik untuk memasang iklan. (Jefkins, 1997 : 2).

Iklan melalui media sosial yang dewasa ini sedang populer merupakan cara yang efektif bagi para pebisnis untuk memperkenalkan produknya karena dinilai sangat mudah, murah dan sasaran pasar yaling pesat. Target iklan melalui media sosial didominasi oleh usia remaja sampai dengan dewasa awal atau dapat dikatakan sebagai kalangan anak muda. Mahasiswa sebagai kalangan anak muda juga menjadi salah satu bagian dari target promosi sosial media yang sangat pesat.

Menurut Ketua Umum P3I Jatim Haries Purwoko mengungkap, secara nasional, belanja iklan tahun ini diperkirakan akan samakin membaik dan peningkatan sebanyak 
11\% sampai 13\%. Peningkatan tersebut diakibatkan oleh kian membaiknya perekonomian nasional. Sentimen positif menandakan bahwa iklan online yang tersiar di sejumlah saluran internet sudah menjadi industri yang menjanjikan seiring perkembangan tatanan ekonomi dunia.

Kemampuan mempromosikan secara online beberapa tahun terakhir ini di satu sisi juga terjadi peningkatan. Bahkan, tak dapat dimungkiri bahwa saluran periklanan online di media sosial semakin berkembang, melebihi iklan, media cetak, antara lain surat kabar harian. Diakui pula bahwa media digital berkaitan secara bertahap terhadap kemajuan saluran kinerja dan biaya iklan secara online. Dengan demikian, perkembangan bisnis periklanan di dunia maya memperlihatkan betapa berharganya pasar digital dewasa ini, terutama dalam berbagai jenis konten komunikasi penjualan iklan dalam menaikkan akses dan kinerja pemasaran produk-produk atau jasa perusahaan di ranah advertisement marketing.

Budaya bisnis masyarakat digital di era kompetisi global ini juga cukup berperan positif untuk membangun citra sejumlah perusahaan melalui periklanan online. Sekumpulan media sosial yang laten untuk memperbesar pasar digital periklanan. Sederhananya, jelas pada tayangan iklan video online sehingga melancarkan untuk dibagikan (share). Netter tertentu kemungkinan memiliki kemampuan tertentu dalam melihat manfaat apa yang terdapat dalam iklan video tersebut.

Media sosial diartikan sebagai media yang tepat untuk pemasaran karena kemudahannya dalam mengakses (Zarella, 2010). Dengan menggunakan media sosial seperti blog maupun media sosial lainnya merupakan Langkah dalam mengurangi biaya promosi, selain itu media sosial lebih berperan dalam memasarkan produk untuk meningkatkan penjualan dibandingkan memasarkan secara konvensional (Ahmed \& Zahid, 2014:546; Pane 2014:13). Andreas Kaplan dan Michael Haenlein (2010) berpendapat bahwa media sosial didefenisikan sebagai sebuah gabungan penggunaan media sosial yang dibangun atas dasar ideologi dan teknologi web 2.0. Selain itu, aplikasi internet sebagai perubahan media yang memberikan pelanggan kekuatan penuh dalam mendapatkan sebuah informasi dan menyampaikan sebuah informasi (Kerpen, 2011).

Luik (2011: 113) terdapat pada buku Komunikasi 2.0, mengatakan bahwa iklan sesuai dengan namanya, media yang tergolong media sosial memiliki fungsi mendukung 
interaksi sosial pada setiap penggunanya. Media sosial sangat memungkinkan seseorang untuk mempertahankan/mengembangkan usahanya, relasi/interaksi relasi sosial dengan orang-orang disekitarnya. Sejalan dengan pemikiran Luik, Ardianto juga menyebutkan bahwa kekuatan media sosial telah merambah sebagai alat menggerakkan massa. Kehadiran media sosial memungkinkan setiap orang menjadi komunikator massa. Apa yang disampaikan seseorang dalam media sosial dapat diakses orang lain dari penjuru dunia lain. Dengan kekuatannya, seakan-akan media sosial melengkapi bahkan menandingi media massa konvensional yang saat ini beroperasi (Luik, 2011:113-114).

Media sosial yang semakin berkembang menawarkan berbagai kemudahan dalam penyebaran informasi yang dapat diakses oleh semua golongan. Perangkat yang digunakan dalam dunia maya merupakan tempat untuk orang-orang berkomunikasi, bertukar pikiran, memberikan informasi dalam bentuk apapun yang dapat diumumkan dengan sederhana dan cepat sehingga mempengaruhi sikap, gaya hidup, serta kebiasaan suatu bangsa. Pada umumnya media sosial merupakan salah satu bentuk perkembangan teknologi yang acap kali digunakan oleh anak muda pada saat ini.

Media sosial menawarkan berbagai kemudahan dalam penyebarluasan dan penerimaan informasi. Faktor inilah yang menjadikan sosial media menjadi salah satu saluran promosi dan penjualan yang wajib digunakan oleh usaha kecil hingga perusahaan-perusahan besar yang bergerak dibidang apapun. Jenis usaha yang memiliki target langsung kepada konsumen dengan jenis usaha berbentuk business to consumers (B2C) menggunakan media sosial sebagai saluran komunikasi sekaligus penjualan. Sedangkan perusahan-perusahan dengan jenis usaha berbentuk business to business (B2B) menggunakan sosial media sebagai media komunikasi dan branding usaha.

Manfaat dari penggunaan sosial media tentu tidak dapat dipungkiri lagi, bahkan untuk usaha juga sebagai saluran komunikasi antara perusahaan, masyarakat umum(pangsa pasar) maupun yang hanya sekedar ingin tahu tanpa niat membeli. Salah satu bentuk media komunikasi yang dapat dilakukan melalui media sosial adalah famplet atau Iklan. Bahasa iklan mampu merekontruksi pesan sampai kepada masyarakat sehingga menjadi sebuah pendangan dan perubahan sikap yang berefek juga pada perubahan perilaku konsumen. Berjalannyawaktu konsumen semakin wellinformed, 
dimana segala produk yang diinginkan dapat diketahui dengan cepat melalui informasi yang tersedia.

Sosial media memberikan kesempatan untuk berinteraksi lebih dekat dengan konsumen, dapat menjadi media untuk membentuk komunitas online. Sosial media dapat menjadi bagian dari keseluruhanemarketing strategy yang digabungkan dengan sosial media lainnya. Serta sebagai jalan menemukan atau menciptakan para brandevangelist. Sosial media memberikan peluang masuk ke komunitasyang telah ada sebelumnya dan memberikan kesempatan mendapatkanfeedbacksecara langsung. Dikatakan juga bahwa dalam menggambarkan perilaku royal maka pelanggan tidak dapat lagi membedakan antara kebutuhan dan keinginan yang belum tercapai atau terpuaskan. Kebutuhan yang dicapai bukan berarti kebutuhan yang dasar melainkan kebutuhan yang hanya sekedar meniru arus mode, ingin mencoba produk baru, ingin memperoleh konsekuensi sosial, tanpa memlihat apakah memang dibutuhkan atau tidak. Dharmmesta dan Handoko (2011)).

Agensi periklanan Zenith Optimedia, milik Publicis dari Perancis berspekulasi, iklan di dunia maya akan mengalami pertumbuhan seiring dengan kelajuan internet dan ekspansi dalam dunia di perangkat mobile. Dilihat dari Reuters, belanja iklan internasional di media sosial akan mendapatkan 20 persen dari seluruh iklan internet pada 2019, sebesar 50 milar dolar dan hanya terdapat satu persen di bawah promosi surat kabar. Iklan di dunia maya di perhitungkan akan melangkahi koran pada 2020. Menurut salah satu tokoh, media sosial dan video online terus mengalami peningkatan untuk pengeluaran iklan dunia.

Informasi prediktif Zenith menyatakan, biaya belanja iklan dunia akan meningkat 4,4 persen di 2017 dan begitupula pada tahun 2016. Agenda besar seperti Olimpiade, berfungsi terhadap iklan tahun ini. Iklan video online juga mengalami peningkatan yang cepat dan mencapai total 35,4 miliar dolar di dunia pada 2019, sedikit melewati radio namun masih di bawah televisi. Belanja iklan dunia normal sejak 2010, pertumbuhannya menurun di Timur Tengah dan Afrika Utara. Zenith memperkirakan China dan sebagian besar Asia tumbuh pesat (bisnis.com/Juni 2017).

Dalam artikel ini, Penulis mengkat Studi kasus tentang peran iklan dalam meningkatkan volume penjualan produk Frestea dari PT. Coca-cola Amatil 
Indonesia. Memasuki era digital seperti sekarang ini berbagai macam industri mengalami perkembangan yang sangat pesat begitupun dengan industri minuman. Menurut Kemenperin, industry minuman dan makanan merupakan salahsatu industri yang memberikan sumbangsi yang besar terhadap PDB dengan mencapai 34,95 persen pada triwulan III tahun 2017. Untuk jenis minumannya sendiri, menurut survei dari Nielsen mengenai beverage share of throat (proporsi penjualan industri minuman dari merek perusahaan tertentu), minuman teh menempati urutan kedua pada angka $23 \%$. Data tersebut menunjukkan tingginya konsumsi terhadap produk dari industri minuman

Angka tersebut memunculkan persaingan yang ketat diantara perusahaanperusahaan dengan produk teh, sehingga mendorong para pelaku industri untuk terus melakukan promosi untuk menjangkau para konsumen atau calon konsumen untuk membeli produknya. Beberapa merek minuman teh kemasan siap minum yang saling berkompetisi untuk menjadi yang terbaik bagi konsumen di Indonesia adalah Teh Botol Sosro, Teh Pucuk Harum, Frestea, Ultra Teh Kotak, Teh Gelas, dll. Untuk mencapai posisi tersebut perlu dilakukan sebuah promosi penjualan. Salah satu alat untuk melakukan promosi penjualan yang digunakan oleh perusahaan agar produk mereka dikenal oleh masyarakat adalah melalui beriklan.

Iklan adalah bentuk promosi yang paling umum digunakan oleh untuk mempromosikan produk suatu perusahaan. Iklan mempunyai tujuan diantaranya untuk mengarahkan orang untuk melakukan tindakan tertentu, misalnya meningkatkan reaksi calon pembeli ataupun pembeli potensial dan menawarkan produk tersebut ke masyarakat. Beberapa produk menggunakan media-media tertentu untuk menanyangkan iklan mereka, salah satunya adalah televisi. Televisi memiliki beberapa kelebihan, seperti daya jangkauan promosi yang lebih luas, fleksibilitas dan selektivitas, fokus perhatian,waktu, serta kreativitas dan juga prestise.

Menurut data dari The Customer Journey (2017), televisi masih menempati posisi tertinggi sebagai media yang baik untuk beriklan. didasarkan pada belanja iklan televisi yang mencapai Rp. 110,46 triliun pada tahun 2018, meningkat sekitar 13\% dibandingkan tahun 2017.

Salah satu merek teh kemasan siap minum yang menggunakan iklan di televisi sebagai promosi penjualannya adalah Frestea dari perusahaan PT Coca-Cola Amatil 
Indonesia. Frestea menempati urutan ketiga dalam belanja iklan dengan total biaya Rp. 298,7 miliar, biaya yang lebih tinggi dibandingkan dengan 8 merek teh kemasan siap minum lainnya. Sedangkan belanja iklan terbesar dipegang oleh Teh Pucuk Harum dengan Rp. 381,7 miliar, diikuti oleh Teh Gelas dengan Rp. 359,6 miliar pada tahun 2016 silam.

Untuk data yang lebih terkini, terhitung selama 7 hari pertanggal $18-25$ Juli 2019 pada adstensity.com, Frestea menghabiskan dana yang besar apabila dibandingkan dengan Teh Pucuk Harum yang menjadi top spender belanja iklan pada tahun 2016 silam. Frestea setidaknya menghabiskan Rp. 4.097.400.000 pada periode tersebut. Sesuai dengan data tersebut, dapat dikatakan bahwa Frestea adalah salah satu produk teh dalam kemasan dengan spending iklan terbesar dibandingkan dengan beberapa kompetitornya.

Dengan budget iklan yang besar untuk mempromosikan produknya, seharusnya calon konsumen telah mendapatkan informasi secara berulang-ulang dari televisi sehingga produk dapat tertanam di benak konsumen dan berkeinginan untuk membelinya. Sayangnya, biaya iklan yang besar tersebut tidak berpengaruh secara signifikan terhadap posisi top brand minuman teh kemasan siap minum. Top Brand adalah penghargaan yang diberikan kepada merek-merek terbaik pilihan konsumen yang menggunakan tiga penilaian yang menjadi acuannya, yakni top of mind, last usage, dan future intention.

Bedasarkan data dari Top Brand, dapat dilihat bahwa posisi TBI Frestea fluktuatif. Persentasi tahun 2016 hanya mencapai angka 7,2\%, tahun 2017 nilainya menurun menjadi 6,3\%, tahun 2018 nilainya meningkat menjadi 9,2\%, tahun 2019 nilainya kembali menurun di angka 8,5\%. Oleh aplikasi Jakpat kemudian dilakukan survei terhadap 5.268 responden dengan perbandingan $55 \%$ pria dan $45 \%$ wanita berusia 16-50 tahun terkait dengan Konsumsi Teh di tahun 2016. Survei mengenai merek teh yang dikonsumsi terakhir tersebut memberi gambaran bahwa hanya 5\% dari total responden saja yang mengonsumsi Frestea terakhir kali.

Permasalahan lain juga dihadapi oleh Frestea pada tahun 2014 - 2016, yakni penurunan data penjualan produk. Bedasarkan data dari SWA (Apriyani, 2017) meskipun penjualan mengalami peningkatan pada tahun 2014-2015 yakni dari Rp 109.470.000.000 menjadi Rp. 116.743.600.000, penjualan pada tahun 2016 mengalami penurunan yang 
cukup signifikan yakni hanya mencapai Rp. 86.000.000.000 saja. Berbanding terbalik dengan biaya iklan yang dikeluarkan oleh Frestea untuk promosi produknya.

Data diatas menunjukkan bahwa Frestea bukanlah pilihan utama konsumen teh kemasan siap minum di Indonesia apabila dibandingkan dengan merek-merek kompetitornya. Bahkan posisinya berada dibawah Teh Kotak dan Nu Green Tea yang belanja iklannya lebih rendah dibandingkan dengan Frestea. Selain melalui pesan yang diterima melalui iklan, sebelum calon konsumen mengambil keputusan pembelian sebuah produk, terdapat banyak faktor yang mempengaruhinya. Salah satunya adalah komunikasi word of mouth yang dimana ialah penyampaian pesan kepada konsumen akan bisnis yang akan diberitahukan, terkhusus kepada target pasar sehingga mereka mendapatkan informasi tentang keunggulan produk dibanding tawaran saingan dengan produk yang semakin beragam pula.

Bedasarkan data dari Nielsen, 89\% konsumen Indonesia yang mempercayai bentuk rekomendasi word of mouth. Global Trust in Advertising dari Nielsen (2015), ditemukan bahwa iklan yang diperoleh dari komunikasi word of mouth secara tatap muka menempati urutan pertama dengan tingkat presentase kepercayaan serta keinginan mengambil tindakan masing-masing sebesar $84 \%$.

Sebagai kesimpulan dari studi kasus diatas adalah Peran iklan terhadap volume penjualan Frestea memiliki pengaruh yang sangat signifikan dan terhadap keputusan pembelian produk Frestea. Sehingga semakin tinggi terpaan iklan Frestea terhadap media periklanan akan berpengaruh terhadap peningkatan persentase pembelian produk Frestea. Sehingga semakin tinggi terpaan iklan Frestea maka akan meningkatkan persentase pembelian produk Frestea. Selain itu komunikasi word of mouth berpengaruh sangat signifikan dan positif terhadap peningkatan pembelian produk Frestea. Sehingga semakin tinggi faktor komunikasi word of mouth juga akan berpengaruh terhadap semakin meningkatnya penjualan produk Frestea.

\section{KESIMPULAN}

Iklan merupakan sarana komunikasi terhadap produk yang disampaikan melalui berbagai media dengan biaya pemrakarsa agar masyarakat tertarik akan apa yang 
ditawarkan. Iklan secara sederhana juga merupakan instrumen atau sarana untuk mempromosikan dan memasarkan barang dalam masyarakat industrial. (Pujiyanto.2001:3-4). Ketika industri berkembang makin masif, dan berbagai produk industri budaya mulai ditawarkan ke masyarakat, konsumen makin beragam dan kompetetif, maka yang terjadi kemudian adalah masing-masing kekuatan komersial mau tidak mau harus memanfaatkan iklan dan mengembangkan strategi yang benar-benar efektif untuk menebus pasar, dan memperluas pangsa pasar yang menjadi pelanggan setia produk-produk yang mereka hasilkan.

Pada dasarnya Periklanan adalah bagian dari kehidupan industry modern, dan hanya bisa ditemukan di negara-negara maju atau negara-negara yang tengah mengalami perkembangan ekonomi yang pesat. Kebutuhan akan adanya periklanan berkembang seiring dengan ekspansi penduduk dan pertumbuhan kota-kota yang dipenuhi oleh banyak toko, restoran, dan pusat perdagangan besar. Perkembangan periklanan juga ikut dipengaruhi oleh tumbuhnya pola-pola produksi secara massal di berbagai pabrik. Terbukanya jaringan komunikasi darat (dalam bentuk jalan raya dan rel-rel kereta api) yang mengalirkan berbagai barang dari satu tempat ke tempat lain, serta terbitnya suratsurat kabar popular yang menjadi tempat menarik untuk memasang iklan. (Jefkins, 1997 : 2).

Kekuatan pasar saat ini berada di tangan konsumen, dimana konsumen yang memegang peranan penting dalam menentukan pilihan dan memutuskan pembelian produk yang dibutuhkannya. Dalam hal ini perusahaan harus mampu menimbulkan minat beli konsumen tersebut demi mencapai tujuan dari perusahaan. Konsumen memiliki minat untuk membeli suatu produk di dasari oleh beberapa faktor-faktor, yaitu faktor promosi yang dilakukan oleh perusahaan dan citra merek perusahaan sehingga konsumen berminat untuk membeli produk yang ditawarkan perusahaan tersebut.

Iklan melalui media sosial yang saat ini sedang trend merupakan cara yang efektif bagi para pebisnis untuk memperkenalkan produknya karena dinilai sangat mudah, murah dan sasaran pasar yaling pesat. Target iklan melalui media sosial didominasi oleh usia remaja sampai dengan dewasa awal atau dapat dikatakan sebagai kalangan anak muda. 
Mahasiswa sebagai kalangan anak muda juga menjadi salah satu bagian dari target promosi sosial media yang sangat pesat.

Kinerja periklanan secara online beberapa tahun terakhir ini di satu sisi juga makin meningkat. Bahkan, tak dapat dimungkiri bahwa akses periklanan online di medsos kini kian bersayap luas, melampaui iklan media cetak, antara lain surat kabar harian. Diakui pula bahwa media digital berimplikasi secara bertahap terhadap pertumbuhan akses kinerja dan belanja iklan secara online. Dengan demikian, pertumbuhan bisnis periklanan di medsos menunjukkan betapa berharganya pasar digital dewasa ini, terutama dalam berbagai jenis konten komunikasi pemasaran iklan dalam meningkatkan akses dan kinerja pemasaran produk-produk atau jasa perusahaan di ranah advertisement marketing.

\section{DAFTAR PUSTAKA}

Adhawiyah, Yahya Robiatul dkk. Peran Pemasaran Media Sosial Dalam Menciptakan Keputusan Pembelian Melalui Kesadaran Merek. Jurnal Ekonomika. Vol.14, No.2, Oktober 2019.

Dewi, Maharani Adhitia. Pengaruh Iklan Online Melalui Instagram Terhadap Keputusan Pembelian Bagi Peningkatan Penjualan Produk Kuliner Lokal. Jurnal Ekonomi I, Vol.3. No. 1, April 2018 hal.11-22

Kristiani, Nuning. Analisis Pengaruh Iklan Di Media Sosial Dan Jenis Media Sosial Terhadap Pembentukan Perilaku Konsumtif Mahasiswa Di Yogyakarta. Jurnal Bisnis dan Ekonomi (JBE), Maret 2017, Hal. 196 - 201 Vol. 24, No. 2 ISSN: 1412-3126

Khoiro, dkk. Pengaruh Promosi Media Sosial Terhadap Keputusan Pembelian Dengan Viral Marketing Sebagai Variabel Intervening. Jurnal Manajemen, 2017.

Perdana, Andre Nico. Pengaruh Promosi terhadap Volume Penjualan pada CV.Rown Division Surakarta Universitas Muhammadiyah Surakarta. (Surakarta 2014), hlm.1.

Primatika Azizah Roza, Astuti Tri Rahayu Sri. Analisis Pengaruh Periklanan Dan Promosi Penjualan Terhadap Keputusan Pembelian Melalui Ekuitas Merek Sebagai Variabel Intervening Pada Produk Nescafe Di Kota Semarang. Volume 7, Nomor 2 , Tahun 2018, Halaman 1-13 ISSN (Online): 2337-3792

Pujiyanto. Strategi Pemasaran Produk Melalui Media Periklanan. Nirmana Vol.5,No.1. Tahun 2003: 96-109. 
Purbohastuti, Wahyuni Arum. Efektivitas media sosial sebagai media promosi. Jurnal Ekonomika. Vol.12, No.2, Oktober 2017.

Puspitarini Sekar dina dan Nuraeni Reni. Pemafaatan Media Sosial Sebagai Media Promosi. Jurnal Common, Vol.3, No.1 Juni 2019.

Poluan, Jane G dkk. The Influencer Of Advertising on the Coca-cola Purchasing Decisions (case study in PT Bangun Wenang Beverage Company Manado). Jurnal EMBA. Vol.4 No.3, September 2016, hal.671-681

Rahayu, SWD. Efektifitas Promosi dalam Meningkatkan Penjualan Produk Kosmetik di Kota Blitar. Akuntabilitas: Jurnal Ilmu-ilmu Ekonomi, Vol. 12, No.1 Tahun 2019.

Romdony, Jefry dkk. Peran Media Sosial Dalam Mendukung Pemasaran Produk Organisasi Bisnis. Ikraith Ekonomika Vol.1, No.2, November 2018

Saputra. Randi. Pengaruh Iklan Dan Citra Merek Terhadap Minat Beli Konsumen Produk Merek Honda. JOM FISIP Vol. 5 No. 1 - April 2018

Sihombing, Dedy Saputra dan Fauzi Ahmad. Pengaruh Periklanan Terhadap Penjualan. Jurnal Administrasi Bisnis (JAB). Vol.71, No 1 Juni 2019.

Siregar, Sari Gusnida dan Widodo Arry. Pengaruh Periklanan Sosial Media Terhadap Keputusan Pembelian konsumen. e-Proceeding of Management. Vol.5, No.1 Maret 2018.

Soelistyowati, Dinar. Peran Youtube dalam Membangun Brand Image bagi pengguna Aplikasi Go-Jek. DiMCC Conference Proceeding, Vol.1, 2018

Sucahyo, Adi Febrian. Analisis Harga dan Promosi terhadap Volume Penjualan padaToko Olahraga Sport Smart oleh Mahasiswa fakultas ilmu keguruan UNY Universitas Negeri Yogyakarta", (Yogyakata: UNY Universitas Negeri Yogyakarta, 2014), hlm.1.

Suyanto, Bagong. 2013. Sosiologi Ekonomi. Kencana: PT Kharisma Putra Utama

Tasruddin, Ramsiah. Tren Periklanan Di Media Sosial. Jurnal Komodifikasi Volume 5, Juni 2017, hal 15-20.

Watie, Setya Dwi. Periklanan Dalam Media Baru. The Messenger, Volume IV, Nomor 1, Edisi Januari 2012

Musdalifah, I. (2013). Eksistensi Bmt Di Tengah Masyarakat Ekonomi Asean ( Studi Kasus Pada Bmt Sinar Surya Makassar ).

Sirajuddin, \& Tamsir. (2019). Rekonstruksi Konseptual Kepemilikan Harta Perspektif Ekonomi Islam (Studi Kritis Kepemilikan Harta Sistem Ekonomi Kapitalisme). Laa Maisyir. 